\title{
Alpha-synuclein alters differently gene expression of Sirts, PARPs and other stress response proteins: implications for neurodegenerative disorders
}

\author{
J. Motyl ${ }^{1}$ • P. L. Wencel $^{2}$ • M. Cieślik ${ }^{1}$ • R. P. Strosznajder ${ }^{2}$ • J. B. Strosznajder ${ }^{1}$
}

Received: 13 June 2016/Accepted: 21 November 2016 /Published online: 3 January 2017

(C) The Author(s) 2016. This article is published with open access at Springerlink.com

\begin{abstract}
Alpha-synuclein (ASN) is a presynaptic protein that can easily change its conformation under different types of stress. It's assumed that ASN plays an important role in the pathogenesis of Parkinson's and Alzheimer's disease. However, the molecular mechanism of ASN toxicity has not been elucidated. This study focused on the role of extracellular ASN (eASN) in regulation of transcription of sirtuins (Sirts) and DNA-bound poly(ADP-ribose) polymerases (PARPs) proteins crucial for cells' survival/death. Our results indicate that eASN enhanced the free radicals level, decreased mitochondria membrane potential, cells viability and activated cells' death. Concomitantly eASN activated expression of antioxidative proteins (Sod2, Gpx4, Gadd45b) and DNA-bound Parp2 and Parp3. Moreover, eASN upregulated expression of Sirt3 and Sirt5, but downregulated of Sirt1, which plays an important role in cell metabolism including $A \beta$ precursor protein (APP) processing. eASN downregulated gene expression of APP alpha secretase (Adam10) and metalloproteinases Mmp2, Mmp10 but upregulated Mmp11. Additionally, expression and activity of pro-survival sphingosine kinase 1
\end{abstract}

Joanna Motyl and Przemysław Wencel equally contributed to this study.

Electronic supplementary material The online version of this article (doi:10.1007/s12035-016-0317-1) contains supplementary material, which is available to authorized users.

R. P. Strosznajder

rstrosznajder@imdik.pan.pl; rstrosznajder@yahoo.com

1 Department of Cellular Signalling, Mossakowski Medical Research Centre, Polish Academy of Sciences, 5 Pawińskiego Street, Warsaw, Poland

2 Laboratory of Preclinical Research and Environmental Agents, Department of Neurosurgery, Mossakowski Medical Research Centre, Polish Academy of Sciences, 5 Pawińskiego Street, 02-106 Warsaw, Poland
(Sphk1), Akt kinase and anti-apoptotic protein $B c l 2$ were inhibited. Moreover, higher expression of pro-apoptotic protein Bax and enhancement of apoptotic cells' death were observed. Summarizing, eASN significantly modulates transcription of Sirts and enzymes involved in APP/A $\beta$ metabolism and through these mechanisms eASN toxicity may be enhanced. The inhibition of Sphk1 and Akt by eASN may lead to disturbances of survival pathways. These results suggest that eASN through alteration of transcription and by inhibition of pro-survival kinases may play important pathogenic role in neurodegenerative disorders.

Keywords Alpha-synuclein · Sirtuins · PARPs $\cdot$ Amyloid · Neurodegeneration $\cdot A D$

$\begin{array}{ll}\text { Abbreviations } & \\ \text { A30P } & \alpha \text {-synuclein mutated protein } \\ \text { A53T } & \alpha \text {-synuclein mutated protein } \\ \text { AD } & \text { Alzheimer's disease } \\ \text { ADAM10 } & \text { alpha-secretase } \\ \quad \text { (gene name } & \\ \text { Adam10) } & \\ \text { AIF } & \text { apoptosis-inducing factor } \\ \text { APP } & \text { amyloid precursor protein } \\ \text { ASN } & \text { alpha-synuclein } \\ \text { ATP } & \text { adenosine triphosphate } \\ \text { A } \beta & \text { amyloid beta } \\ \text { BACE1 (gene } & \text { beta-site amyloid precursor protein } \\ \text { name Bace1) } & \text { cleaving enzyme 1 } \\ \text { Bax (gene name } & \text { pro-apoptotic Bcl-2 protein } \\ \text { Bax) } & \\ \text { Bcl-2 (gene } & \text { anti-apoptotic Bcl-2 protein } \\ \text { name Bcl2) } & \end{array}$




\section{Bclx-L (gene name Bcl2l1) \\ CCCP}

Cyb5b (gene
name $C y b 5 b$ )
DCF
DMEM
E45K
eASN
ETC
EDTA
FBS
Gadd45b
(gene name
Gadd45b)
GPx-4 (gene
name Gpx4)
H2DCF-DA

HSP

LB

MMP 2, 10, 11

(gene name

Mmp2, 10, 11)

МPP+/MPTP

MSS/HPLC

MTT

NAD

PAR

PARP 1, 2, 3

PBS

PC12

PD

p-FTY720

PGC1 $\alpha$

PI3K/Akt

PJ-34

Psen1, 2

(gene name

Psen1, 2)

ROS anti-apoptotic Bcl-2 protein

carbonyl cyanide 3-

chlorophenylhydrazone

(mitochondrial uncoupler)

cytochrome b5

2'7'-dichlorofluorescein

Dulbecco's Modified Eagle Medium

$\alpha$-synuclein mutated protein

extracellular acting ASN

electron transport protein complexes

ethylenediaminetetraacetic acid

fetal bovine serum

anti-apoptotic protein growth arrest

and DNA damage inducible beta

glutathione peroxidase 4

2',7' dichlorodihydrofluorescein

diacetate

heat shock protein

Lewy body

metalloproteinase $2,10,11$

1-methyl-4-phenylpyridinium/

1-methyl-4-phenyl-1,2,3,

6-tetrahydropyridine

mass spectrometry/high performance

liquid chromatography

3-(4,5-dimethylthiazol-2-yl)-2,

5-diphenyltetrazolium bromide

nicotinamide adenine dinucleotide

poly(ADP-ribose)

poly(ADP-ribose) polymerase

$1,2,3$

phosphate buffer saline

pheochromocytoma cell line

Parkinson's disease

FTY720 Phosphate, 2-amino-2[2-

(4-octylphenyl)ethyl]-1,3-propanediol, mono dihydrogen phosphate ester

Peroxisome proliferator-activated receptor (PPAR) $\gamma$ coactivator $1 \alpha$ phosphatidylinositol-3-kinase/Akt

$\mathrm{N}-$-6-Oxo-5,6-dihydrophenanthridin-

2-yl)-(N,N-dimethylamino)acetamide

hydrochloride, specific PARP inhibitor

presenilin 1,2

reactive oxygen species
S1P sphingosine-1-phosphate

SDS-PAGE sodium dodecyl sulfate polyacrylamide

gel electrophoresis

SEW2871 $\quad \mathrm{S}_{1} \mathrm{P}_{1}$ receptor agonist

SIRT 1, 2, 3, 4, 5 sirtuin 1, 2, 3, 4, 5

(gene name

Sirt1, 2, 3, 4, 5)

SOD2 (gene superoxide dismutase 2

name Sod2)

Sphk1 sphingosine kinase 1

\section{Introduction}

Alpha-synuclein (ASN) is a 140 -amino acid soluble protein that is abundantly expressed in the nervous system, where it constitutes $1 \%$ of total cytosolic proteins [1-3]. In physiological conditions, ASN occurs in presynaptic terminals in close proximity to synaptic vesicles. ASN is involved in the regulation of synaptic vesicle transport and in the formation of synaptic connections, their structure and plasticity [4-7]. The data of Bartels et al. 2011 [8] indicate that ASN occurs physiologically as a helically folded tetramer that is resistant to aggregation. The tetramer can dissolve into unfolded monomers which subsequently can aggregate into soluble protofibrils and insoluble $\beta$-amyloid fibres [9]. Recent data have indicated that alterations in ASN expression and conformation could play an important role in familial (A30P, A53T mutations) and in sporadic forms of Parkinson's disease (PD) as well as in the pathology of about $60 \%$ of Alzheimer's disease's (AD) cases [10-13]. Misfolding of this protein leads to aggregation/ fibrilisation of ASN, which in $\beta$-sheet structure is toxic to cells [14-16]. The aggregates of ASN are the main components of intracellular inclusions called Lewy bodies (LBs), which are the pathological hallmarks of PD, ADforms with LBs and other synucleinopathies [17-21]. The latest studies including our data demonstrate that ASN could be secreted from neuronal cells and nerve endings into the extracellular space [12, 22, 23]. Extracellular alphasynuclein (eASN) can alter ionic homeostasis and synaptic transmission in neuronal cells [24, 25]. Several recent studies support the hypothesis that, just as the human prion protein, ASN can transfer protein alteration from cell to cell [26, 27]. Recently, ASN was detected in rodent and human brain interstitial fluid, which confirms that it is secreted outside the cell. eASN affects neuronal and glial homeostasis, activates inflammatory reactions and promotes neuronal death [12, 28-32]. Moreover, eASN induces amyloid-beta (A $\beta$ ) secretion and enhances the level of the amyloid-beta precursor protein (APP), and in this way it potentiates its own and $A \beta$ toxicity [11, 23, 27, 33-36]. The mechanism of ASN secretion is not well understood, however, oxidative stress seems to have a promoting role in this process $[12,22,29]$. 
Our last study indicated that ASN secretion is also modulated by the pharmacological inhibition of sphingosine kinase(s) (Sphk1/2) [22] and this effect is probably mediated by free radical-dependent processes. These enzymes are responsible for the synthesis of sphingosine-1phosphate (S1P), a pleiotropic lipid mediator which exerts a mitogenic, pro-survival but also pro-apoptotic effects within the cell [37-40]. Sphk1/2 are key enzymes that maintain homeostasis between $\mathrm{S} 1 \mathrm{P}$ and ceramide, and through this mechanism they may play an important role in the regulation of cell survival and death. The inhibition of Sphk1/2 alters S1P-dependent signalling, regulated also by the PI3K/Akt pathway. The three from five receptors (S1P1, S1P2 and S1P3) are specific for S1P transduce information by PI3K/Akt. Our last data indicated the neuroprotective effect of S1P $(1 \mu \mathrm{M})$ in dopaminergic cellsexposed to different types of stress [41-43]. The lower S1P concentration has been described in AD [40, 44], in the dopaminergic SH-SY5Y cell PD model and also in the animal PD model evoked by 1-methyl-4-phenylpyridinium MPP+/MPTP, respectively [22, 41, 45]. The alteration of $\mathrm{S} 1 \mathrm{P}$ level in AD correlated well with reduced expression/ activity of Sphk1/2 and with the ratio of dementia.

Another important role in regulation of cell viability is played by nicotinamide adenine dinucleotide (NAD) dependent enzymes such as sirtuins (SIRTs) and DNA-bound poly(ADP-ribose) polymerases (PARPs). The enzyme families of SIRTs and PARPS are engaged in the regulation of energy metabolism, anti-oxidative processes, DNA repair and cell survival [46-49]. In mammalian cells, there are seven members of the sirtuins family (SIRTs 1-7), among which SIRT1 has been the most investigated. Recently, it was found that SIRT1 protects cells against ASN and protein Tau aggregation. The lifespan of mouse is increased by overexpressing SIRT1 and decreased by knocking out SIRT1 in brain [50-52]. SIRT1 activates alpha-secretase gene expression (Adam 10) and supresses amyloid beta (A $\beta$ ) production [53]. Alpha-secretase activates APP processing inside the A $\beta$ sequence and in this way prevents formation of neurotoxic $A \beta$. Degradation of APP by alpha-secretase leads to release of soluble, neuroprotective terminal domain of APP. Several metalloproteinases as ADAM10, ADAM17, ADAM9 express alpha-secretase activity [54]. Moreover, SIRT1 activates peroxisome proliferator-activated receptor (PPAR) $\gamma$ coactivator $1 \alpha(\mathrm{PGC} 1 \alpha)$ and through this mechanism it increases mitochondrial biogenesis [47]. Among mitochondrial located SIRTs, SIRT3 was the best investigated and it was demonstrated that this enzyme is responsible for the regulation of electron transport protein complexes (ETC) and for expression and activity of several anti-oxidative proteins, e.g. superoxide dismutase (SOD2) and glutathione peroxidase $(\mathrm{GPx})$, which are crucial in the molecular mechanism of cell viability [46]. The roles of other mitochondrial SIRTs, SIRT4 and SIRT 5 is not fully understood. Outeiro et al. [55] found that inhibition of cytosolic SIRT2 protects against ASN toxicity in vitro and in the Drosophila model of PD. It was indicated that this cytosolic-located SIRT2 exerted the opposite effect than pro-survival SIRT1 [49]. The other NAD-regulated enzyme family (17 members) of PARPs, as compared to SIRTs, exhibits higher affinity to the $\beta \mathrm{NAD}^{+}$particle $[56,57]$. The most important enzyme of this family is DNA-bound PARP1, which in the brain is responsible for more than $90 \%$ of poly-ADP-ribosylation processes [58, 59]. Also PARP2 and PARP 3 are DNA-bound enzymes, and all of them are activated in stress and are involved in the DNA repair mechanism under middle stress [60]. However, under massive DNA damage, PARP1 can be over-activated and responsible for apoptotic or necrotic cell death $[58,61,62]$.

In this study we investigated the role of eASN in the regulation of gene expression of SIRTs, PARPs and enzymes involved in the APP/A $\beta$ metabolism. Moreover, the expression and activity of Sphk1 and Akt under eASN toxicity were analysed.

\section{Materials \& Methods}

\section{Aggregation of a-synuclein}

The ASN protein was subjected to the aggregation/ oligomerisation procedure as described in Danzer et al. [33] with some modifications. Lyophilised ASN (from rPeptide, USA) was dissolved in $1 \mathrm{ml}$ mixture of $50 \mathrm{mM}$ sodium phosphate buffer, $\mathrm{pH} 7.0$, containing $20 \%$ ethanol, to a final concentration of ASN $10 \mu \mathrm{M}$. After $4 \mathrm{~h}$ of shaking at room temperature (RT) using a thermomixer 5436; Eppendorf, Wesseling-Berzdorf, Germany), the ASN protein was lyophilised again and resuspended in $0.5 \mathrm{ml}$ mixture of $50 \mathrm{mM}$ sodium phosphate buffer, $\mathrm{pH} 7.0$, containing $10 \%$ ethanol. Then it was mixed for $24 \mathrm{~h}$ with open lids to evaporate the residual ethanol. Concentrations of obtained ASN forms were determined using spectrophotometric measurement (NanoDrop) with absorbance at 280/290 nm.

\section{Verification of ASN Purity and Structure}

The purity of the ASN protein was determined using mass spectrometry/HPLC. Then aliquots containing $2 \mu \mathrm{g}$ of the ASN protein prepared after the procedure as described above (Danzer et al. [33]) were analysed by SDS-PAGE followed by silver staining. The analysis indicated that ASN before and after the described procedure was in monomeric/oligomeric form. Then the ASN pure protein before and after the aggregation/oligomerisation procedure was analysed by circular dichroism (CD) on a JASCO J-815 CD spectropolarimeter 
in the range of $\sim 270-195 \mathrm{~nm}$ with a data pitch of $1.0 \mathrm{~nm}$. ASN before the procedure was in a random coil structure which was no longer observed after the aggregation/oligomerisation procedure. This indicated that the structure of ASN changed into the $\beta$-sheet structure. In addition, the conformation state of ASN was confirmed using Thioflavin T (ThT, benzothiazole dye) fluorescence.

\section{Cell Culture and Cell Treatment Protocol}

Rat pheochromocytoma (PC12) cells were cultured in Dulbecco's Modified Eagle's Medium (DMEM) supplemented with $10 \%$ heat-inactivated fetal bovine serum (FBS), $5 \%$ heat inactivated horse serum, $2 \mathrm{mM}$ L-glutamine, $50 \mathrm{U} / \mathrm{ml}$ penicillin and $50 \mu \mathrm{g} / \mathrm{ml}$ streptomycin in a $5 \% \mathrm{CO} 2$ atmosphere at $37^{\circ} \mathrm{C}$. Cell treatment was performed in low-serum (2\% FBS) DMEM to stop proliferation. The PC12 cells were used for experiments between five and ten passage numbers. For the MTT assay, the PC12 cells were seeded onto collagencoated 96-well plates at a density of $7 \times 10^{4}$ cells per well in $100 \mu \mathrm{l}$ of medium. For other analyses, the PC12 cells were seeded at $3 \times 10^{5}$ cells/10-mm tissue culture dishes. Then the PC12 cells were treated with eASN $(0.5 \mu \mathrm{M}$ for 24-48 h). Control cells were treated with sodium phosphate buffer subjected to the same oligomerisation procedure as the eASN. Additionally, cells were treated with Z-DEVD-FMK (R\&D Systems), Cyclosporin A (Sigma-Aldrich, 30024), SEW2871 (Cayman Chemical), p-FTY720 (Cayman Chemical), AK-7 (Sigma-Aldrich, SML0152), PJ-34 (Sigma-Aldrich), Resveratrol (Sigma-Aldrich), Quercetin (Sigma-Aldrich). Appropriate solvent was added to respective controls.

\section{Cytotoxicity Assays}

\section{Cell Viability Analysis (MTT Assay)}

Mitochondrial function and cellular viability were evaluated using 2-(4,5-dimethylthiazol-2-yl)-2,5-diphenyltetrazolium bromide (MTT). After $48 \mathrm{~h}$ incubation with the appropriate compounds, MTT $(2.5 \mathrm{mg} / \mathrm{ml})$ was added to all of the wells. The cells were incubated at $37{ }^{\circ} \mathrm{C}$ for $2 \mathrm{~h}$. Then the medium was removed, the formazan crystals were dissolved in DMSO and absorbance at $595 \mathrm{~nm}$ was measured.

\section{Trypan Blue Staining}

Trypan blue solution was added to the culture medium. The cells were examined immediately under an optical microscope. The number of blue stained cells and the total number of cells were counted. If cells took up trypan blue, they were considered nonviable.
Determination of Apoptosis Using Hoechst 33342 Fluorescent Staining

For morphological studies, PC12 cells were subjected for 24$96 \mathrm{~h}$ to oxidative stress evoked by eASN $(0,5 \mu \mathrm{M})$. PC12 cells were collected and washed in PBS. The cells were fixed in $\mathrm{MetOH}$ for $30 \mathrm{~min}$ in $4 \mathrm{C}$. Nuclei were visualised with Hoechst $33342(0.2 \mu \mathrm{g} / \mathrm{ml}$, Riedel-de-Haën Germany) fluorescent staining. The cells were examined under a fluorescence microscope (Olympus BX51, Japan) and photographed with a digital camera (Olympus DP70, Japan). Cells with typical apoptotic nuclear morphology (nuclear shrinkage, condensation) were identified and counted. The results were expressed as apoptotic index according to the equation apoptotic index $=$ (apoptotic ratio/average apoptotic ratio for control) where apoptotic ratio $=($ apoptotic cells $) /($ all cells $)$.

\section{Mitochondrial membrane potential ( $\Delta \Psi m)$ assay}

Detection of mitochondrial membrane potential $(\Delta \Psi \mathrm{m})$ was performed using the JC-1 detection kit (Thermo Fisher Scientific) according to the manufacturer's directions. JC-1 $\left(5^{\prime}, 6,6^{\prime}\right.$ tetrachloro-1,1',3,3'-tetraethylbenzimidazolylcarbocyanine iodide) is a cationic dye which accumulates in mitochondrial membranes of healthy cells, resulting in red fluorescence $(590 \mathrm{~nm})$, while in apoptotic and necrotic cells, which have diminished mitochondrial membrane potential, JC-1 exists in the green fluorescent $(529 \mathrm{~nm})$ monomer form. Images are captured using a fluorescence image scanning unit (FMBIO III) instrument (flow cytometer) and the ratios of red (live cells) and green (dead cells) fluorescence were calculated. All assays were performed in quadruples and repeated twice.

\section{Determination of Free Radicals Using 2'7'-dichlorofluorescein (DCF)}

The level of reactive oxygen species (ROS) was determined using 2',7' dichlorodihydrofluorescein diacetate (H2DCF-DA) exactly as described previously by Cieślik et al. 2015 [63].

\section{Determination of Sphk1 Activity}

Sphingosine kinase activity assay was performed according to the method of Don et al. 2007 [64], as described previously [22, 41]. After $24 \mathrm{~h}$ incubation, the PC12 cells were washed with iced PBS and lysed in $50 \mathrm{mM}$ Hepes, $\mathrm{pH} 7.4,15 \mathrm{mM}$ $\mathrm{MgCl}_{2}, 10 \mathrm{mM} \mathrm{KCl}, 10 \%$ glycerol, $2 \mathrm{mM}$ ATP, $5 \mathrm{mM} \mathrm{NaF}$, $1 \mathrm{mM}$ deoxypyridoxine, and EDTA-free complete protease inhibitor (Roche Applied Science). Lysates were cleared by centrifugation at $15000 \mathrm{~g}$ for $5 \mathrm{~min}$. The $100 \mu \mathrm{g}$ of lysates and NBD-Sphingosine (10 $\mu \mathrm{M}$ final) (Avanti Polar Lipids) were 
mixed in reaction buffer, $50 \mathrm{mM}$ Hepes, $\mathrm{pH} 7.4,15 \mathrm{mM}$ $\mathrm{MgCl}_{2}, 0.5 \%$ Triton X-100, $10 \%$ glycerol, $2 \mathrm{mM}$ ATP and incubated for $30 \mathrm{~min}$ at $30{ }^{\circ} \mathrm{C}$. The reactions were stopped by the addition of an equal amount of $1 \mathrm{M}$ potassium phosphate $(\mathrm{pH} 8.5)$, followed by the addition of 2.5 -fold chloroform/methanol (2:1), and then centrifuged at $15000 \mathrm{~g}$ for $1 \mathrm{~min}$. Only the reactant NBD-S1P, but not the substrate NBD-sphingosine, was collected in the alkaline aqueous phase. After the addition of an equal volume of dimethylformamide, the fluorescence value was determined $(\lambda \mathrm{ex}=485 \mathrm{~nm}, \lambda \mathrm{em}=538 \mathrm{~nm})$.

\section{Immunochemical Determination of Protein Level (Western Blot)}

The PC12 cells were washed three times with ice-cold PBS, scraped from the culture dishes and suspended in 1x Cell Lysis Buffer (from Cell Signalling Technology). Protein levels were determined using the Lowry method [65], and the proteins were mixed with $5 \times$ Laemmli sample buffer and denatured for $5 \mathrm{~min}$ at $95^{\circ} \mathrm{C}$. A total of $50 \mu \mathrm{g}$ of the protein was loaded per lane on $7.5 \%, 10 \%$ or $15 \%$ acrylamide gels and separated by sodium dodecyl sulfate (SDS)-polyacrylamide gel electrophoresis. The proteins were transferred onto a nitrocellulose membrane at $10 \mathrm{~V}$ overnight at $4{ }^{\circ} \mathrm{C}$. The quality of transfer was verified with Ponceau S staining. The membranes were incubated in 5\% dry milk in TBS with Tween 20 (TBS-T) for $1 \mathrm{~h}$ at RT and exposed overnight at $4{ }^{\circ} \mathrm{C}$ to the following antibodies: anti-Sphk1 (Cell Signalling Technology, 1:500), anti-pAkt and anti-Akt (Cell Signalling Technology, at a dilution of 1:1000), anti-SIRT1 (Santa Cruz Biotechnology, 1:1000) and anti-Gapdh (Sigma-Aldrich, 1:50 000). After treatment for $1 \mathrm{~h}$ with the corresponding horseradish peroxidase-coupled secondary antibodies (anti-rabbit from Amersham Biosciences or anti-mouse from GE Healthcare), the protein bands were detected by chemiluminescent reaction using ECL reagent (Amersham Biosciences). GAPDH was detected on membranes as a loading control. Densitometric analysis and size-marker-based verification were performed using Total Lab 4 software. After detection, the membranes were treated with stripping buffer (50 mM glycine, $\mathrm{pH} 2.5$, $1 \%$ SDS) for further blots.

\section{Determination of Gene Expression}

The PC12 cells were washed twice with ice-cold PBS and suspended in $1 \mathrm{ml}$ of TRI reagent (Sigma-Aldrich). RNA was isolated from the cell pellet according to the manufacturer's protocol. Digestion of DNA contamination was performed by using DNase I according to the manufacturer's protocol (Sigma-Aldrich). Reverse transcription was performed using a High Capacity cDNA Reverse Transcription Kit according to the manufacturer's protocol (Applied
Biosystems, Foster City, CA, USA). The level of mRNA for selected genes was analysed using TaqMan Gene Expression Assays (Applied Biosystems, Foster City, CA, USA) according to the manufacturer's instructions: Bax: Rn01480161_g1, Bcl2: Rn99999125 m1, Bcl2ll: Rn00437783 m1, Adam10: Rn01530753_m1, Bace1: Rn00569988_m1, Psen1: Rn00569763 m1, Psen 2: Rn00579412 m1, Sod1: Rn00566938_m1, Sod2: Rn00690588_g1, Cyb5b: Rn00577982_m1, Gadd45b: Rn01452530_g1, Gpx4: Rn00820818_g1, Sirt1: Rn01428096_m1, Sirt2: Rn01457502_m1, Sirt3:Rn01501410_m1, Sirt4: Rn01481485_m1, Sirt5:Rn01450559_m1, Parp1: Rn00565018_m1, Parp2: Rn01414610_m1, Parp3: Rn01447502_m1, Mmp2: Rn01538170_m1, Mmp9: Rn00579162_m1, Mmp10: Rn00591678_m1, Mmp11: Rn01428817_m1, Actb: 4352340E. Actb was selected and used in all of the studies as a reference gene. Quantitative PCR was performed on an ABI PRISM 7500 apparatus. The relative levels of mRNA were calculated using the $\Delta \Delta \mathrm{Ct}$ method.

\section{Statistical Analysis}

The results were expressed as mean values \pm SEM. Differences between the means were analysed using a Student's t-test for two groups or one-way analysis of variance ANOVA with the Newman-Keuls post hoc test among multiple groups, $p$ values $<0.05$ were considered significant. The statistical analyses were performed using Graph Pad Prism version 5.0 (Graph Pad Software, San Diego, CA, USA).

\section{Results}

In the present research, we studied the molecular mechanism of eASN evoked cytotoxicity leading to a cells' death. The study was focused on the role of eASN in regulation of gene expression of sirtuins, DNA-bound PARPs and other stress response proteins engaged in regulation of cell survival/death. The MSS/HPLC analysis of ASN used in this study indicated its purity (Fig. 1a). It was found that ASN which was used for the experiments, adopted the monomeric/oligomeric forms (Fig. 1b). Using circular dichroism (CD) it was observed that ASN was in random coil structure (Fig. 1c), which changed during the aggregation/oligomerization procedure into the $\beta$ sheet structure - confirmed by thioflavin $\mathrm{T}$ fluorescence determination (Fig. 1d).

This study demonstrated that exogenous, extracellularly applied eASN in monomeric/oligomeric form significantly enhanced the free radicals level in a concentration-dependent manner (Fig. 2a) and concomitantly reduced PC12 cells' viability (Fig. 2b). About $50 \%$ of cells show low viability at $0.5 \mu \mathrm{M}$ of eASN and this concentration was further used. 
a

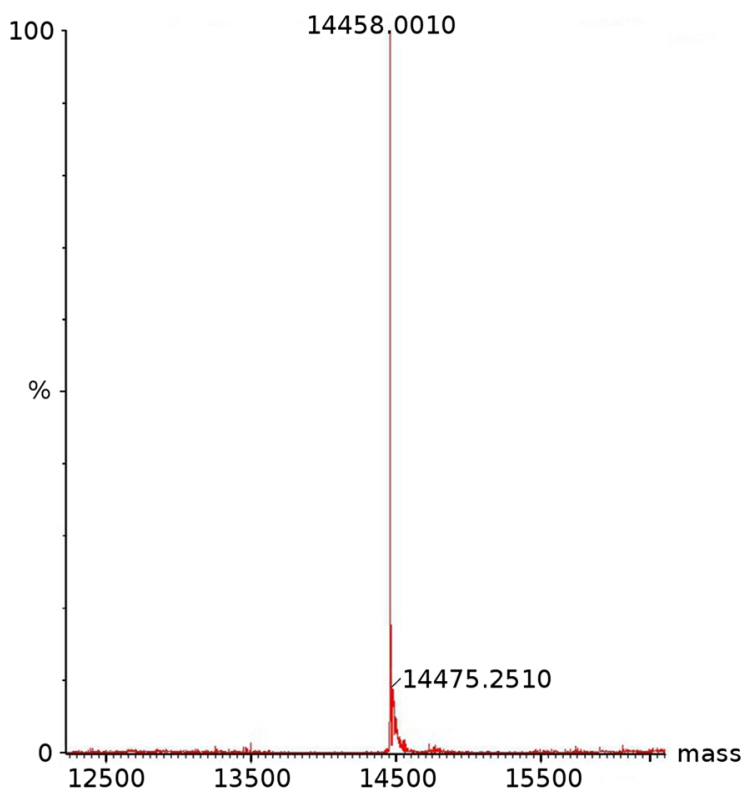

C

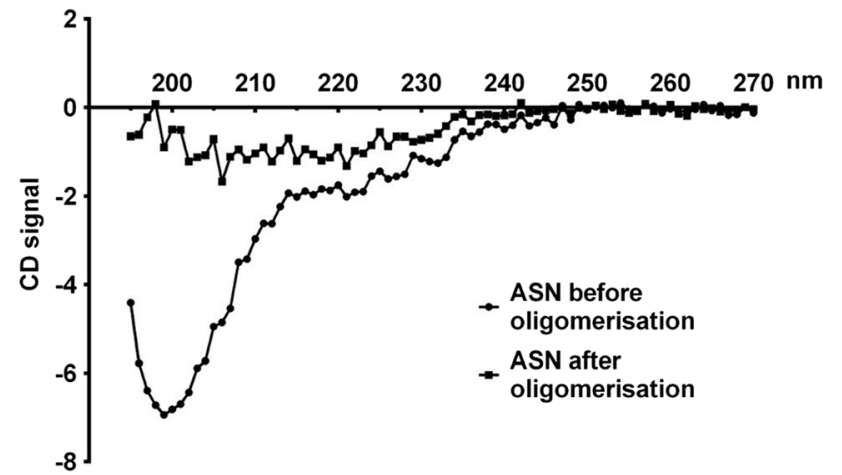

b

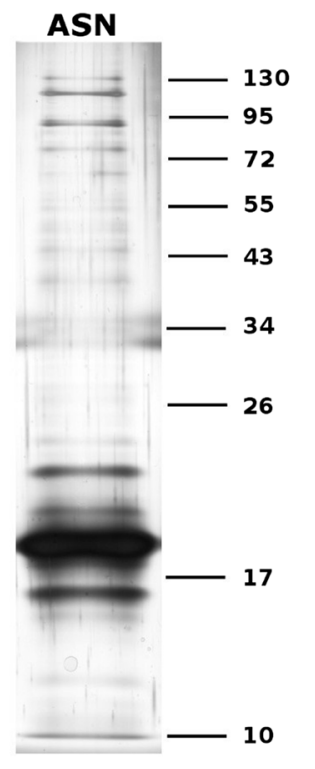

d

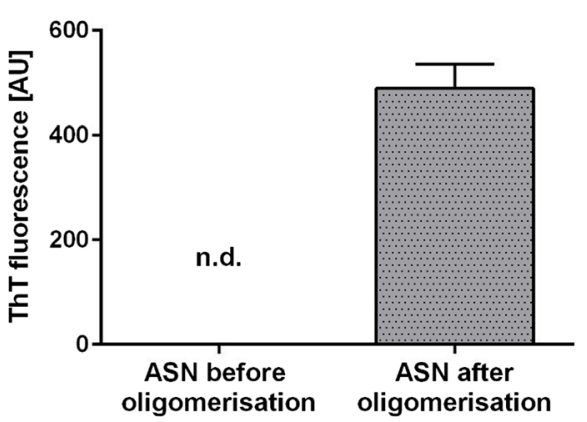

Fig. 1. Determination of eASN purity and structure. eASN used for aggregation /oligomerisation procedure $(\mathrm{A} / \mathrm{O})$ was subjected to MMS/ HPLC analysis of its purity in $50 \mathrm{mM}$ sodium phosphate buffer, $\mathrm{pH} 7.0$ before and after the $\mathrm{A} / \mathrm{O}$ procedure (a). Then the electrophoretic analysis of the eASN aggregation forms was performed. $2 \mu \mathrm{g}$ of protein before and after the $\mathrm{A} / \mathrm{O}$ procedure was subjected to non-denaturing electrophoresis followed by silver staining (b). The presence of eASN

For analysing the effect of eASN on cells' viability, the mitochondrial membrane potential (MMP) using JC-1 staining was evaluated. eASN significantly decreased MMP by about $20 \%$ comparing to the control cells (without eASN) (Fig. 2c). Experiments with trypan blue staining demonstrated a significant increase in number of dead cells under the eASN toxicity conditions (Fig. 2d).

The eASN evoked stress may lead to activation of cytoprotective processes to counteract free radicals mediated damages of macromolecules. We determined the transcription level of selected enzymes involved in antioxidative defence against eASN toxicity. eASN significantly increased the mRNA level of the mitochondrial anti-oxidative enzymes: superoxide dismutase 2 ( $\operatorname{Sod} 2$ ), glutathione peroxidase 4 monomers, dimers and trimers was reported. In the next step eASN before and after the $\mathrm{A} / \mathrm{O}$ procedure was subjected to analysis of circular dichroism spectra of eASN in $50 \mathrm{mM}$ sodium phosphate buffer, $\mathrm{pH} 7.0$ (c). Note the significant differences in spectra before and after eASN oligomerisation procedure. Finally, analysis of Thioflavin T(ThT) fluorescence before and after eASN oligomerisation was done (d)

(Gpx4) as well as Gadd45b (anti-apoptotic protein growth arrest and the DNA-damage-inducible beta) (Fig. 3a). There was no significant effect of eASN on Sod1 and cytochrome b5 $(C y b 5 b)$ gene expression (Fig. 3a). Moreover, DNA-bound PARPs expression was determined under eASN evoked oxidative stress. Gene expression of Parpl was not altered by eASN, but Parp2 and Parp3 were significantly upregulated (Fig. 3b). The protein level of the mitochondrial apoptosis-inducing factor (AIF) regulated by PARP/PAR was not changed as compared to the control conditions (data not shown). The recent studies demonstrated the significant role of other NAD dependent enzymes sirtuins (SIRTs) in the regulation of anti-oxidative defence in cells. Our results showed that mRNA level of Sirt3 and Sirt5 (mitochondria located enzymes) was significantly 
Fig. 2. The effect of eASN on ROS generation, $\mathrm{PC} 12$ cells' viability, mitochondrial membrane potential and cells' death. PC12 cells were treated with $0,125-2 \mu \mathrm{M}$ eASN for $48 \mathrm{~h}$. ROS generation was determined using DCF probe (a), cell viability by MTT assay (b), mitochondrial membrane potential determined by JC-1 staining (c), cells' death by Trypan Blue staining (d). Data represent the mean value \pm S.E.M of four-six independent experiments with four to six replications. ${ }^{*} \mathrm{p}<0.05, * * \mathrm{p}<0.01$ and $* * * p<0.001$ versus control (phosphate buffer - treated PC12 cells) by one-way ANOVA followed by the Newman-Keuls post-hoc test.
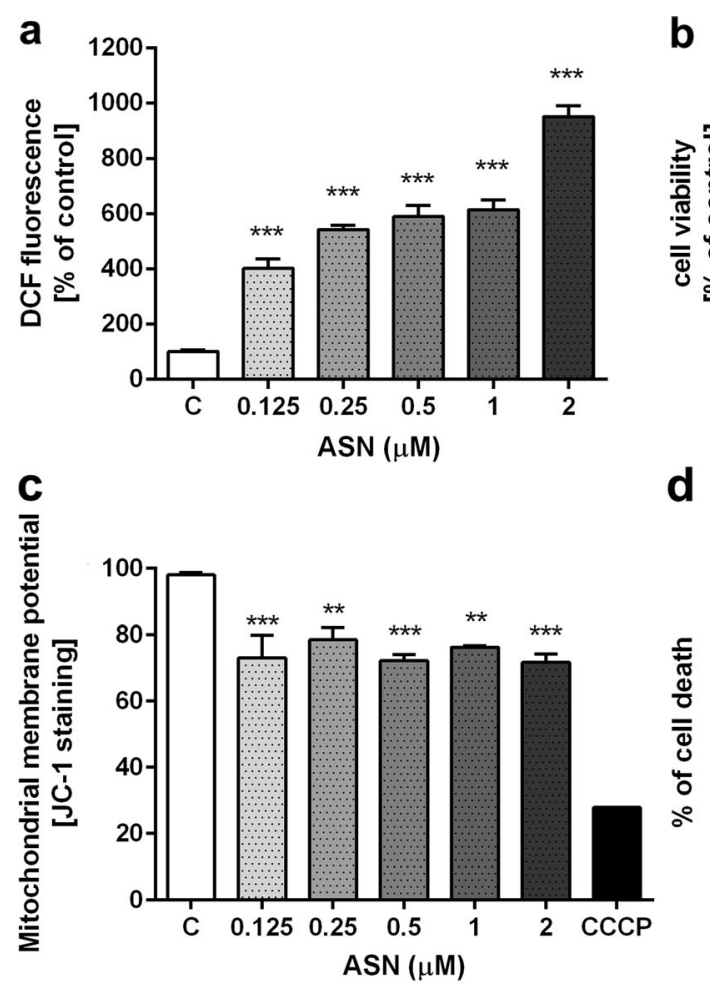
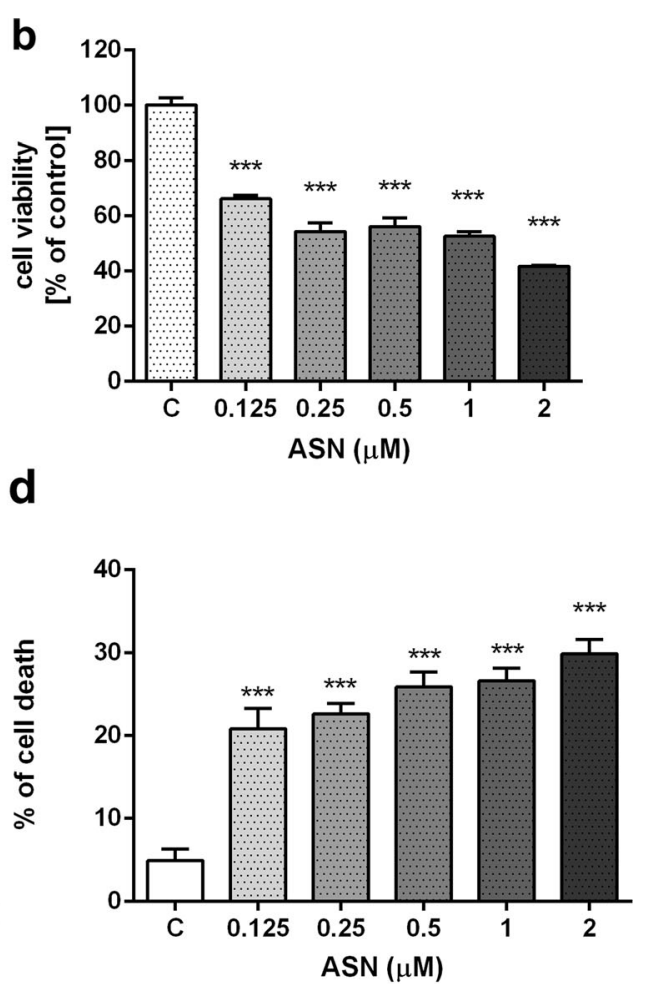

enhanced, but expression of Sirt1 was significantly decreased and Sirt2, 4 were not altered (Fig. 3c).

Our previous study indicated close relationship between ASN and APP levels. Moreover, it was found that ASN enhanced A $\beta$ peptides secretion and its toxicity leading to irreversible alterations in cells viability [11]. In this study the effect of eASN on expression of enzymes engaged in APP metabolism and in degradation of $A \beta$ peptides was investigated. Our results demonstrated significant downregulation of gene expression of $\alpha$-secretase (Adam10), the key enzyme in non-amyloidogenic
Fig. 3. The effect of eASN on gene expression of anti-oxidative enzymes and DNA-bound PARPs. The mRNA level of Sod1, Sod2, Gpx4, Gadd45b, Cyb5b (a), Parp1,2,3 (b), Sirt 1,2,3,4,5 (c) after $24 \mathrm{~h}$ of $0,5 \mu \mathrm{M}$ eASN treatment was measured with real-time PCR. The value expresses the fold of the above gene stimulation normalized against $A c t b$ ( $\beta$ actin). Data represent the mean value \pm S.E.M of four separate experiments. The relative level of mRNA was calculated by $\Delta \Delta \mathrm{Ct}$ method. $* \mathrm{p}<0.05$, and $* * * \mathrm{p}<0.001$ versus control (phosphate buffer -treated PC12 cells) by Student's t-test.
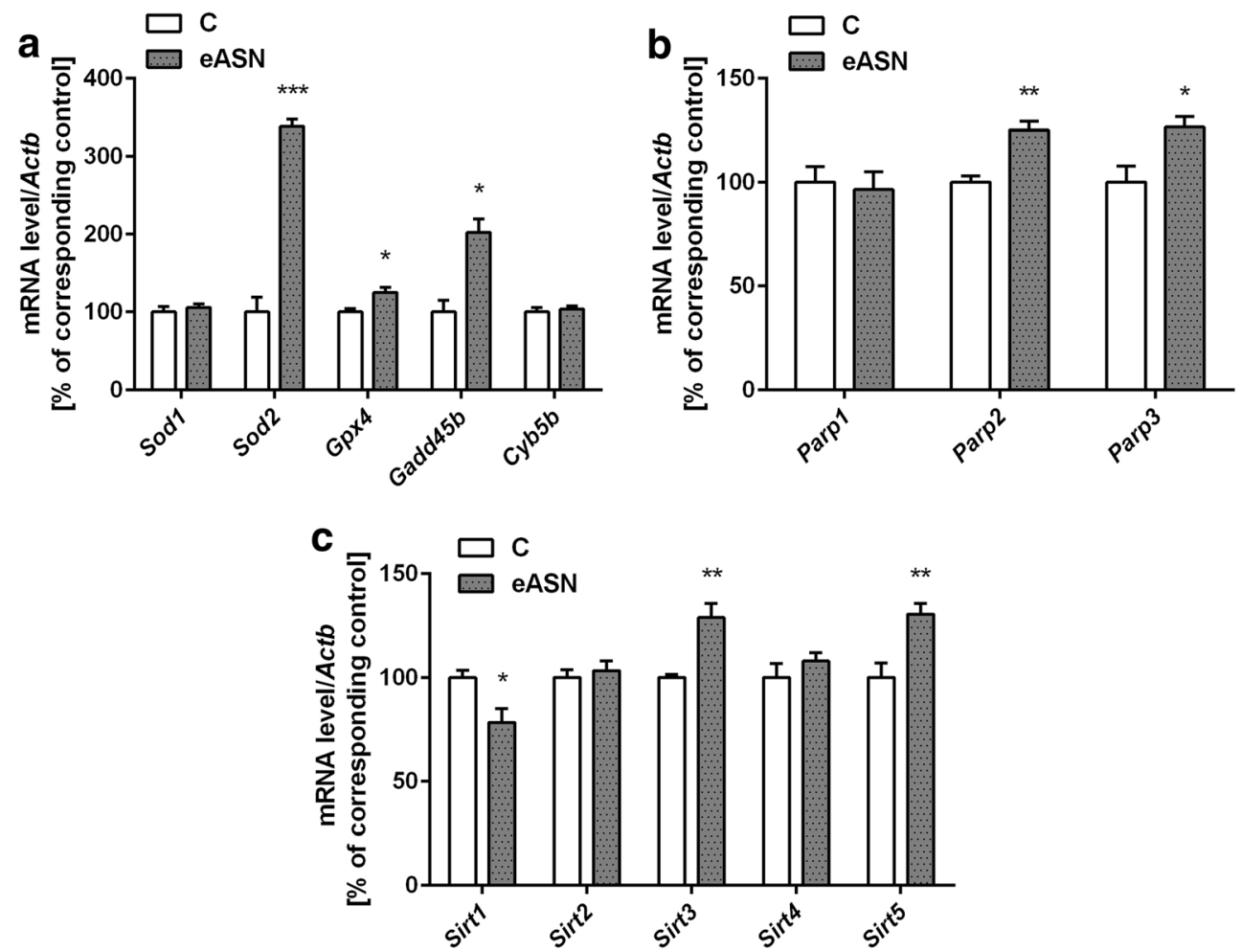


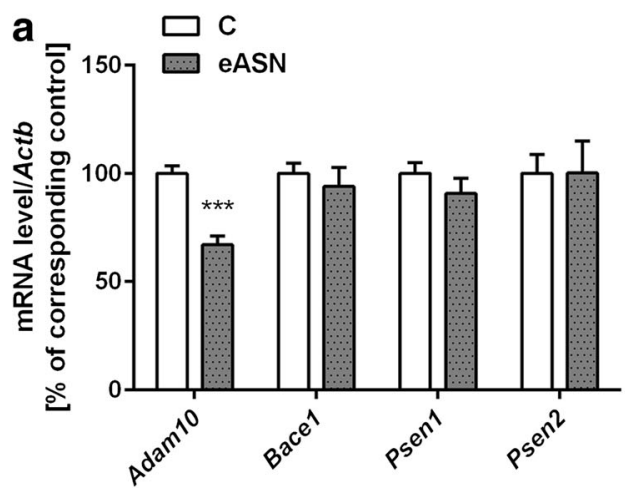

Fig. 4. Effect of eASN on gene expression of selected $A \beta$ secretases and metalloproteinases. The mRNA level of Adam10, Bace1, Psen1, Psen 2 (a) and Mmp2,9,10,11 (b) after $24 \mathrm{~h}$ of $0,5 \mu \mathrm{M}$ eASN treatment was measured with real-time PCR. The value expresses the fold of the above gene stimulation normalized against Actb ( $\beta$-actin). Data

APP processing (Fig. 4a). eASN had no effect on gene expression of $\beta$-secretase (Bacel) and also did not affect $\gamma$-secretase crucial subunits, presenilin 1 and presenilin 2 (Psen1,2) (Fig. 4a). However, eASN decreased gene expression of Mmp2 and Mmp10 and upregulated gene expression of Mmp11 (Fig. 4b).

Other crucial enzymes involved in regulation of cell survival and death are sphingosine kinase (SphK1) and PI3K/Akt kinase. It was found that eASN induced a significant decrease in the activity and protein level of Sphk1 (Fig. 5a, b). Similar effects as eASN were exhibited by ASN-mutated forms, i.e. A30P, E46K and A53T on PC12 cells' viability and the Sphk1 activity (Fig. S1a, b). It was observed that eASN also decreased the pro-survival pathway regulated by Akt kinase. The protein level of total Akt was not altered (Fig. 6a), but significantly lower phosphorylation of Akt kinase on serine 473 was observed, which may be responsible for its lower activity (Fig. 6b). In consequence, the ratio of phospho-Akt to total Akt was significantly lower after ASN treatment as compared to the control value (Fig. 6c). It was previously shown that Akt inhibits cells' death by preventing the release of cytochrome $\mathrm{c}$ from

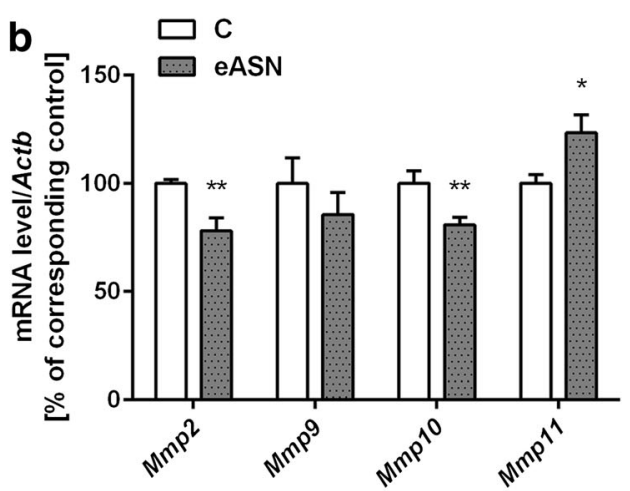

represent the mean value \pm S.E.M of four-six separate experiments with four replications. The relative level of mRNA was calculated by $\Delta \Delta \mathrm{Ct}$ method. $* * \mathrm{p}<0.01$ and $* * * \mathrm{p}<0.001$ versus control(phosphate buffer treated PC12 cells) by Student's t-test

mitochondria and by regulation of pro and anti-apoptotic Bcl-2 proteins. Our study indicated that eASN enhanced expression of the pro-apoptotic $\mathrm{Bcl}-2$ protein, $\mathrm{Bax}$, and downregulated the anti-apoptotic protein $B c l 2$ (Fig. 7a). Moreover, eASN activated apoptotic cells' death was visualised by nuclei staining (Hoechst 33342) (Fig. 7b). Representative pictures showed enhanced number of cells with typical apoptotic morphological changes in cell nuclei characterized by nuclear shrinkage, chromatin condensation and nuclear fragmentation (Fig. 7c).

Furthermore, we also analysed several compounds as S1P analogues (SEW2871, p-FTY720), the caspase inhibitor (ZDEVD-FMK) and an inhibitor of the inner mitochondria membrane permeability (Cyclosporin A) in order to evaluate their potentially protective effect against eASN. As a result no effect of those compounds on cells' viability was observed. Moreover, neither Resveratrol nor quercetin, specific SIRT2 inhibitor (AK-7) nor inhibitor of PARP-1 (PJ-34) were able to rescue cells against eASN toxicity (Fig. S2).

All described molecular alterations evoked by eASN were demonstrated on Fig. 8. a

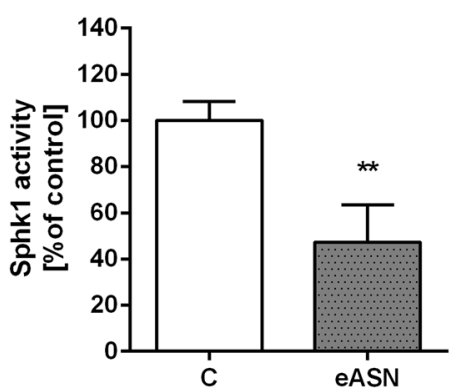

b

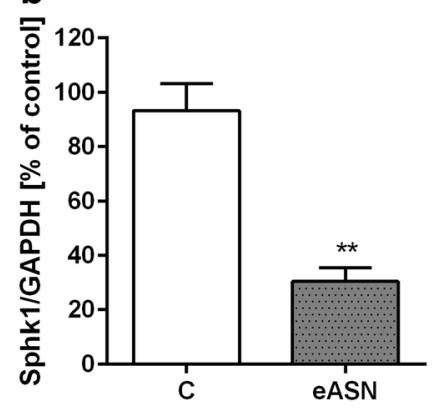

Sphk1 ( 45 kDa) GAPDH ( $\sim 37 \mathrm{kDa})$

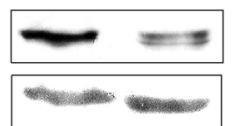

Fig. 5. Sphk1 activity, gene expression/protein level in eASN-treated PC12 cells. PC12 cells were treated with $0,5 \mu \mathrm{M}$ eASN for $24 \mathrm{~h}$. Fluorescence value of Sphk1 activity was measured. Data represent the mean value \pm S.E.M of five independent experiments (a). Sphk1 $(\sim 45$ $\mathrm{kDa}$ ) immunoreactivity in the cells' homogenate was measured. A representative Western blot from one typical experiment is shown below the graph. Data represent the mean value \pm S.E.M of four independent experiments normalized against GAPDH ( $\sim 37 \mathrm{kDa})$ (b). $* \mathrm{p}<0.05$ and $* * \mathrm{p}<0.01$ versus control (phosphate buffer-treated PC12 cells) by Student's t-test. 

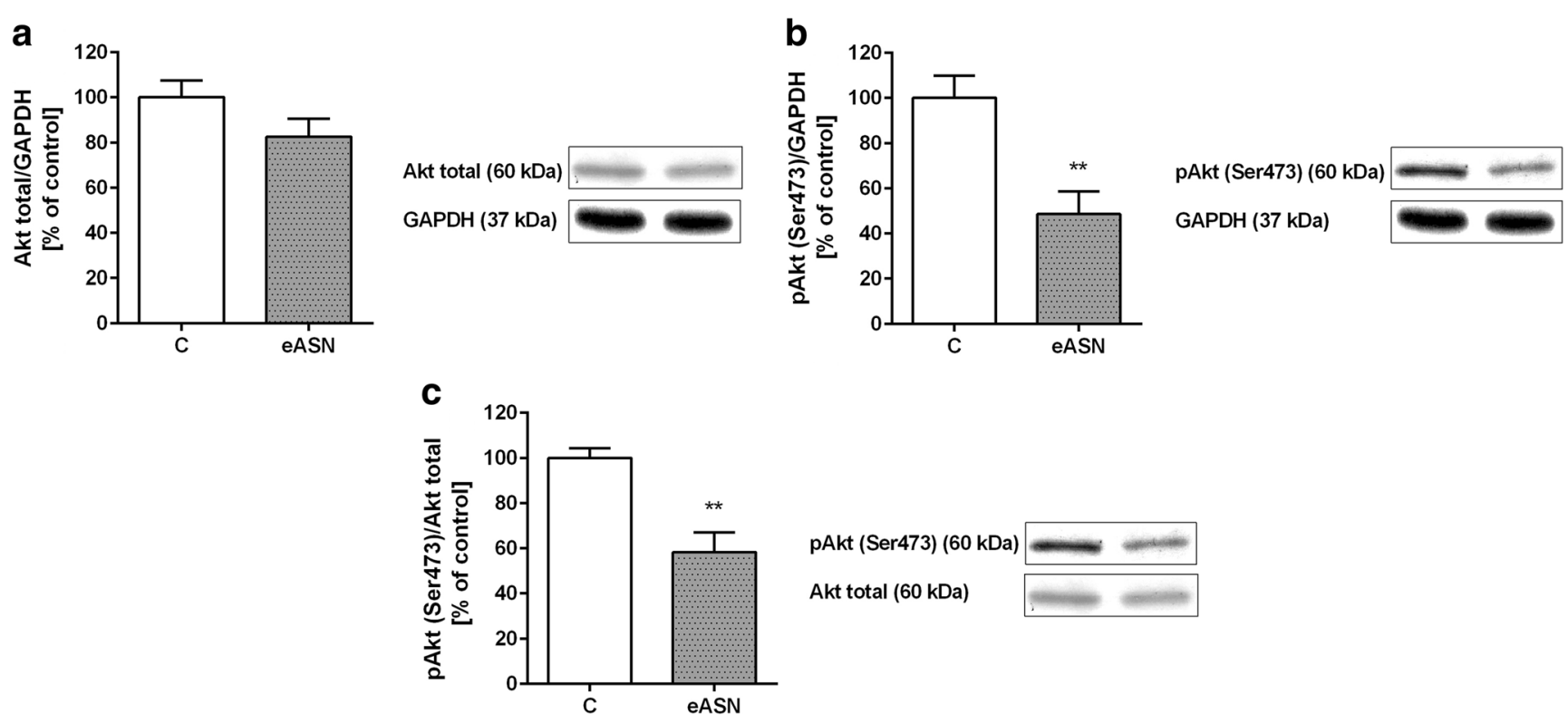

Fig. 6. Akt kinase phosphorylation/activity under eASN toxicity. $\mathrm{PC} 12$ cells were treated with $0,5 \mu \mathrm{M}$ eASN for $24 \mathrm{~h}$. Effect of $0,5 \mu \mathrm{M}$ eASN on the level of immunoreactivity of Akt (pan) (a), pAkt (pSer473, $60 \mathrm{kDa}$ ) (b) and pAkt/Akt (pan) ratio (c) in the cells' homogenate. A representative Western blot from one typical experiment is shown

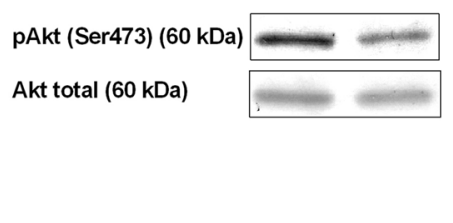

below the graph. Data represent the mean value \pm S.E.M of four independent experiments normalized against GAPDH $(\sim 37 \mathrm{kDa}) \mathbf{( a , b})$. $* * \mathrm{p}<0.01$ versus control (phosphate buffer -treated PC12 cells) by Student's t-test.

\section{Discussion}

Our results showed that eASN may play an important role as a potent regulator of transcription. It differently affects gene expression of SIRT1 and mitochondrial SIRT3 and SIRT5. It was found that eASN decreased mRNA level of SIRT1. Moreover, eASN downregulated the expression of Adam10, the enzyme responsible for non-amyloidogenic APP metabolism. The inhibition of Adam 10 by ASN may disturb the balance between the non-amyloidogenic and amyloidogenic pathways of APP processing. Previous studies showed that SIRT1 deletion decreased lifespan and enhanced ASN aggregates in brain of PD mouse experimental model [50, 51]. The upregulation of SIRT1 leads to suppression of $A \beta$ production by activation of alpha-secretase $[51,53]$. eASN may translocate from extracellular compartment inside the cell and it can influence gene expression directly or by interaction with different transcription factors, however this process is not fully understood [66]. Additionally, it was previously found that ASN significantly upregulated the APP protein level and A $\beta$ secretion $[11,23]$. All the above-mentioned data together indicate the important relationship between ASN/APP/A $\beta$ and suggest that ASN/A $\beta$ interaction can lead to irreversible molecular alterations and to cell death [11]. eASN by inhibition of Adam 10 and by downregulation of gene expression of Mmp2, Mmp10 with concomitant activation of Mmp11 may alter $\mathrm{APP} / \mathrm{A} \beta$ processing and may lead to higher $\mathrm{A} \beta$ production. It was demonstrated that MMP2 and MMP9 may be involved in the $A \beta$ catabolism, as they can degrade $A \beta$ fibrils

in vitro as well as amyloid plaques in brain slices from APP/ PS1 mice. MMPs were found in the brains of AD patients [67-69] and the results indicated that they participated in $\mathrm{A} \beta$ clearance by its degradation. Wan et al. (2015) demonstrated that $A \beta-42$ oligomers induced leakage of the bloodbrain barrier (BBB) and that MMPs may play an important role in this process [70]. Our data demonstrated that ASN significantly decreased the transcription of $M m p 2$ and Mmp 10 which may be responsible for the lower A $\beta$ catabolism leading, in consequence, to a higher $A \beta$ concentration. Moreover, it is possible to suggest that the upregulation of Mmp 11 may enhance APP degradation. It was previously proposed that MMP12 exacerbated the cascade of proteolytic processes by subsequent activation of several MMPs [71]. The involvement of ASN in the APP/A $\beta$ metabolism by downregulation of Adam 10, Mmp2 and Mmp10 expression may have a significant impact on the cells' fate.

Moreover, ASN through the inhibition of pro-survival kinases Sphk1 and Akt could profoundly affect cells' viability. Our results showed that both native and mutated eASN similarly decreased the activity of Sphk1. Recently, we also demonstrated that Sphk1 inhibition stimulated ASN secretion, the release of cytochrome $\mathrm{c}$ from the mitochondria, activated proapoptotic protein expression and led to caspase-dependent dopaminergic cells' death in stress induced by MPP+ [22, 41]. Our studies suggested that Sphk1 inhibition by activation of oxidative stress led to ASN release into the extracellular compartment [22]. Previous data demonstrated the role of oxidative/nitrosative stress in ASN release from the brain 

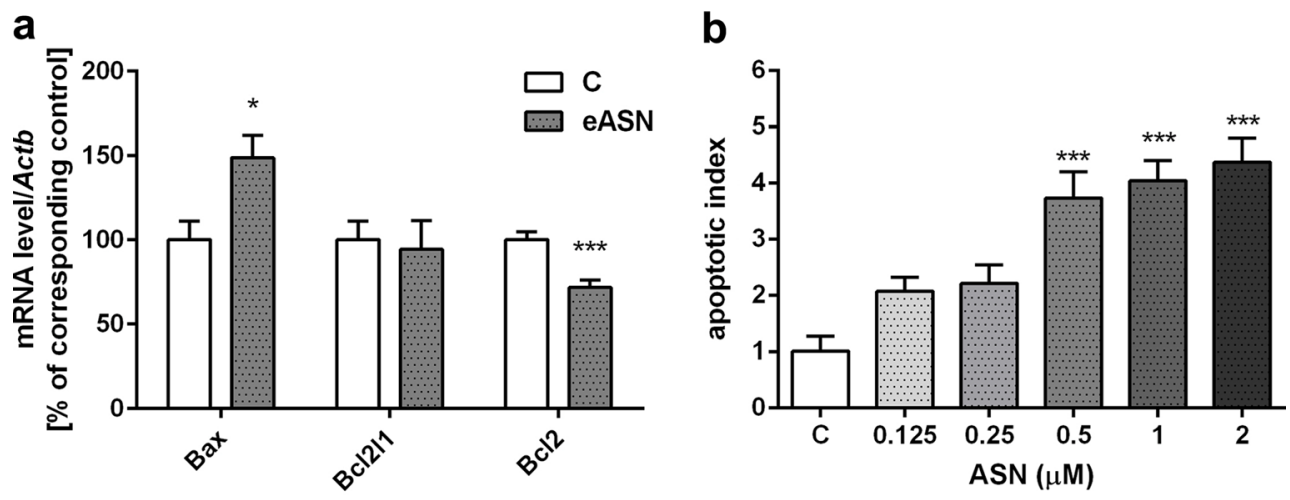

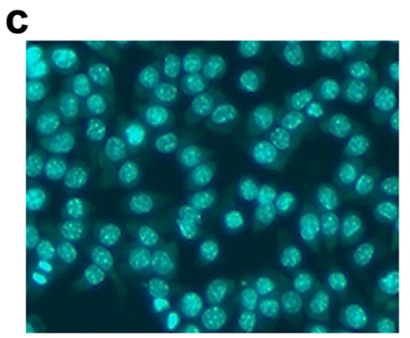

Control

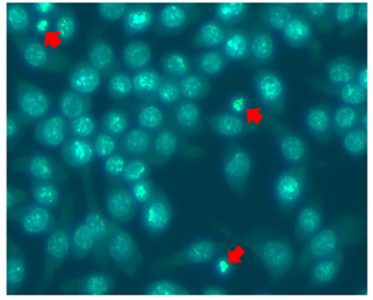

ASN $0.5 \mu \mathrm{M}$

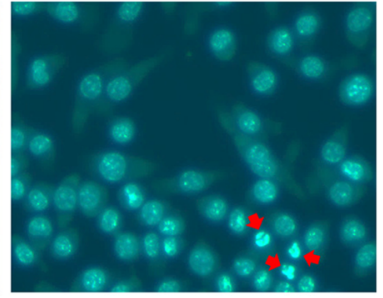

ASN $2 \mu \mathrm{M}$
Fig. 7. The effect of eASN on Bcl-2 pro-apoptotic and anti-apoptotic proteins gene expression and on apoptotic cells' death. The mRNA level of $B a x, B c l 2$ and $B c l 2-L 1$ after $24 \mathrm{~h}$ of $0,5 \mu \mathrm{M}$ eASN treatment was measured with real-time PCR (a). The value expresses the fold of the above gene stimulation normalized against $A c t b$ ( $\beta$-actin). Microscopic examination of cell nuclei, stained with DNA-binding fluorochrome Hoechst 33342. The cells were treated with $0,5 \mu \mathrm{M}$ eASN, 24h. Cells with typical apoptotic nuclear morphology (nuclear shrinkage, chromatin

synaptosomal fraction [29]. Moreover, it was found that eASN induced A $\beta$ release and that prolonged action of ASN $(10 \mu \mathrm{M}$ for $48 \mathrm{~h})$ led to cell death $[11,72]$. In the present work the eASN- evoked Sphk1 decline could also be explained on the basis of the action of reactive oxygen species (ROS). Oxidative stress can regulate Sphk1 expression and activity

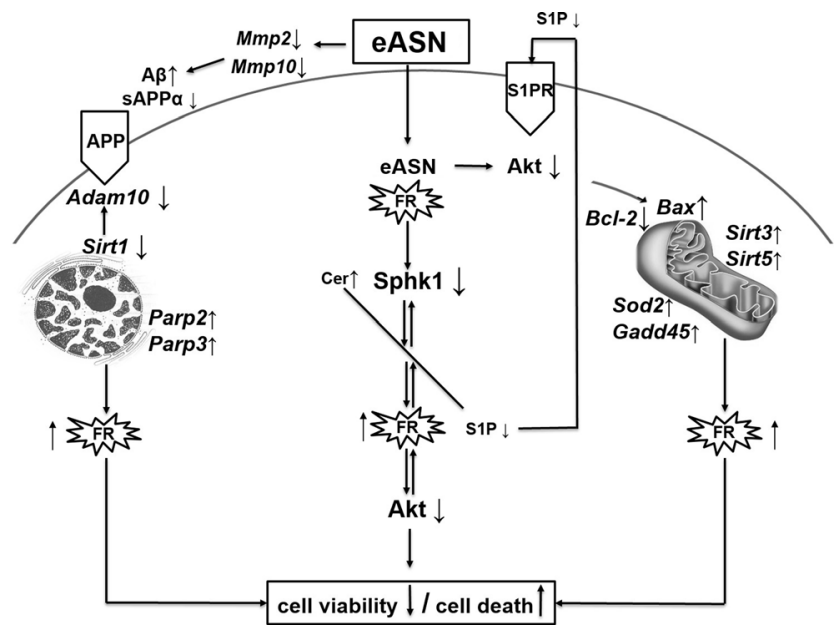

Fig. 8. Schematic representation of eASN evoked alteration of gene expression and molecular changes leading to decrease of cells' viability and to activation of cells' death. condensation) were identified and counted. The results were expressed as percentages of apoptotic cells in the whole cells' population from one exemplary experiment in four to eight replications $(\mathbf{b}, \mathbf{c})$. Data represent the mean value \pm S.E.M of four - eight separate experiments with two replications. The relative level of mRNA was calculated by $\Delta \Delta \mathrm{Ct}$ method. $* * \mathrm{p}<0.01$ versus control(phosphate buffer -treated PC12 cells) by Student's t-test

depending on cell's type and intensity of stress [73]. It was reported that ROS overproduction, induced by $A \beta$ peptides and $\mathrm{MPP}^{+}$, may decrease Sphk1 activity in SH-SY5Y cells $[41,74,75]$. eASN via $\operatorname{Sphk}(\mathrm{s})$ inhibition disturbs the sphingolipid homeostasis, which may lead to lower S1P synthesis, and concomitantly to lower pro-survival signaling through S1P-specific receptors. A growing number of studies have emphasized the important role of bioactive sphingolipids such as S1P and ceramide in the regulation of neuronal cell survival and death, respectively. The sphingolipid equilibrium between S1P and ceramide (also called the sphingolipid rheostat) may be crucial for cell survival $[38,43,73,76]$. Several studies have indicated that an increased ceramide concentration suppressed the viability of dopaminergic neuronal cells $[43,77,78]$. It was also shown that disturbances in the S1P level and signaling could be responsible for the pathomechanism of $\mathrm{AD}$ and other neurodegenerative diseases $[79,80]$. We hypothesized that lower S1P synthesis may be also important in the mechanism of cell death evoked by eASN. Sphk(s) pharmacological inhibition has a similar effect as MPP+ on dopaminergic cell viability [22]. Another very important pro-survival pathway inhibited by eASN is Akt, which is also involved in S1P receptor-mediated signaling. It was demonstrated previously that ASN has a dual effects on 
Akt phosphorylation/activity depending on its structure and concentration [81-83]. In our study eASN significantly reduced Akt phosphorylation/activity which, in consequence, may decrease cells' viability.

There is a strong evidence that ASN overexpression enhances the ROS level $[12,84,85]$. Our previous data showed that eASN enhanced the calcium influx by voltage-dependent calcium channels and disturbed mitochondrial function, which in consequence induced oxidative stress, altered CdK5 and GSK-3 $\beta$ and activated caspase-dependent programmed cell death [11, 86-88]. The production of ROS, which is well established to occur during abnormal protein conformation, e.g. ASN or $A \beta$ peptide oligomerization, could be a common fundamental mechanism in neurodegenerative disorders such as $\mathrm{AD}$ and PD [12, 58, 76, 89, 90]. ASN itself or its fragment(s) directly or through the interaction with different transcription factors can influence gene expression for several important enzymes as SIRT1, $\alpha$-secretase and other proteins as $\mathrm{Bax} / \mathrm{Bcl} 2$. Concomitantly eASN leads to significantly higher expression of $\operatorname{Sod} 2$, which is one of the most important anti-oxidative enzymes responsible for dismutation of superoxide in the mitochondria. Additionally, higher expression of the Gpx4 and Gadd $45 b$ were found.

Moreover, eASN up-regulates Sirt3 and Sirt5 expression, which may have anti-apoptotic properties [46, 91]. The data suggest that SIRT3 may be mainly engaged in the activation of an antioxidative mechanism against ASN toxicity. SIRT1 and SIRT3 play a significant role in the regulation of redox potential, energy and metabolic status of the cell. SIRT1 and SIRT3 deacetylate SOD1 and SOD2, respectively. SIRT1 exerts the effect through the regulation of $\alpha$-secretase, heat shock protein (HSP) $[50,51,92]$ and PGC1- $\alpha$, which results in enhanced mitochondria biogenesis [47]. However, the lower expression of SIRT1 observed in this study may lead to disruption of the SIRT1-PGC1- $\alpha$ relationships. This alteration has been suggested as being of significance for DNA repair impairment and may play an important role in the pathomechanism of neurodegenerative diseases. The role of SIRT5 is not till now fully elucidated. This enzyme is also responsible for protein desuccinylation and demalonylation, and for cytochrome c release from mitochondria.

Lower Sirt1 expression may affect several cellular processes, including PARP1 function. It was reported that SIRT1 has been able to mitigate rapid PARP1 activation in oxidative stress by deacetylated PARP1 reversing its enzymatic stimulation and reducing it activity to nearly undetectable levels. Moreover, SIRT1 has been shown to interact with the DNAbinding domain and, to a lesser extent, with the automodification domain of PARP1 [93]. It was also reported that PARP2 may regulate the activity of the SIRT1 [94] and SIRT1 promotor. We showed that eASN upregulated gene expression for the DNA-bound enzyme PARP2 and PARP3. The previous studies demonstrated the significance of PARP1 in neurodegenerative disorders [95]. There are evidences indicating the role of DNA-bound PARP(s) in regulation of transcription factors, DNA repair and SIRT(s). The relationship between PARP(s) and SIRT(s) may have a significant impact on cells' fate in pathological conditions, including neurodegenerative disorders. These two families of enzymes were previously suggested to compete for the same substrate $\beta \mathrm{NAD}^{+}$. However, recently published data have demonstrated that, opposite to PARP1, the affinity of PARP2 and probably PARP3 to NAD is similar as in the case of SIRT1, and that many functions of PARP2 are independent from NAD $[93,94]$. Our data indicate that eASN may serve as important modulator of transcription and may exert its toxicity through alterations of gene expression of enzymes involved in APP/ $\mathrm{AB}$ metabolism and through inhibition of Sphk1 and Akt mediated signaling. All these data suggest that eASN may have a significant impact on the progression of neurodegenerative disorders.

Acknowledgements This study was supported by a grant of the National Science Centre (NSC); grant no. 2013/09/B/NZ3/01350.

The MSS/HPLC and CD equipment used in this study was sponsored in part by the Centre for Preclinical Research and Technology (CePT), a project co-sponsored by the European Regional Development Fund and Innovative Economy, The National Cohesion Strategy of Poland. The analyses were carried out at the Institute of Biochemistry and Biophysics, PAS in Warsaw with the kind help of Dr. Goch and coworkers.

Open Access This article is distributed under the terms of the Creative Commons Attribution 4.0 International License (http:// creativecommons.org/licenses/by/4.0/), which permits unrestricted use, distribution, and reproduction in any medium, provided you give appropriate credit to the original author(s) and the source, provide a link to the Creative Commons license, and indicate if changes were made.

\section{References}

1. Stefanis L (2012) a -Synuclein in Parkinson's Disease. Cold Spring Harb Perspect Med 1-23. doi: 10.1101/cshperspect.a009399

2. Cookson M (2009) alpha-Synuclein and neuronal cell death. Mol Neurodegener 4:9. doi:10.1186/1750-1326-4-9

3. Dehay B, Decressac M, Bourdenx M et al (2016) Targeting $\alpha$ synuclein: therapeutic options. Mov Disord. doi:10.1002 /mds.26568

4. Vila M, Vukosavic S, Jackson-Lewis Vet al (2000) Alpha-synuclein up-regulation in substantia nigra dopaminergic neurons following administration of the parkinsonian toxin MPTP. J Neurochem 74:721-729. doi:10.1046/j.1471-4159.2000.740721.x

5. Mattila PM, Rinne JO, Helenius H et al (2000) Alpha-synucleinimmunoreactive cortical Lewy bodies are associated with cognitive impairment in Parkinson's disease. Acta Neuropathol 100:285290. doi:10.1007/s004019900168 
6. Auluck PK (2002) Chaperone suppression of alpha -synuclein toxicity in a drosophila model for Parkinson's disease. Science 295(80):865-868. doi:10.1126/science.1067389

7. Fujiwara H, Hasegawa M, Dohmae N et al (2002) alpha-Synuclein is phosphorylated in synucleinopathy lesions. Nat Cell Biol 4:160 164. doi: $10.1038 / \mathrm{ncb} 748$

8. Bartels T, Choi JG, Selkoe DJ (2011) $\alpha$-Synuclein occurs physiologically as a helically folded tetramer that resists aggregation. Nature 477:107-110. doi:10.1038/nature10324

9. Wang W, Perovic I, Chittuluru J et al (2011) A soluble $\alpha$-synuclein construct forms a dynamic tetramer. Proc Natl Acad Sci U S A 108: 17797-17802. doi:10.1073/pnas.1113260108

10. Mikolaenko I, Pletnikova O, Kawas CH et al (2005) Alpha-synuclein lesions in normal aging, Parkinson disease, and Alzheimer disease: evidence from the Baltimore Longitudinal Study of Aging (BLSA). J Neuropathol Exp Neurol 64:156-162

11. Kazmierczak A, Strosznajder JB, Adamczyk A (2008) $\alpha$-Synuclein enhances secretion and toxicity of amyloid beta peptides in PC12 cells. Neurochem Int 53:263-269. doi:10.1016/j. neuint.2008.08.004

12. Wilkaniec A, Strosznajder JB, Adamczyk A (2013) Toxicity of extracellular secreted alphasynuclein: Its role in nitrosative stress and neurodegeneration. Neurochem Int 62:776-783. doi:10.1016/j. neuint.2013.02.004

13. Ryan BJ, Hoek S, Fon EA, Wade-Martins R (2015) Mitochondrial dysfunction and mitophagy in Parkinson's: from familial to sporadic disease. Trends Biochem Sci 40:200-210. doi:10.1016/j. tibs.2015.02.003

14. Lashuel HA, Petre BM, Wall J et al (2002) $\alpha$-synuclein, especially the parkinson's diseaseassociated mutants, forms pore-like annular and tubular protofibrils. J Mol Biol 322:1089-1102. doi:10.1016 /S0022-2836(02)00735-0

15. Uversky VN, Li J, Fink AL (2001) Evidence for a partially folded intermediate in alpha- synuclein fibril formation. J Biol Chem 276: 10737-10744. doi:10.1074/jbc.M010907200

16. Winner B, Jappelli R, Maji SK et al (2011) In vivo demonstration that alpha-synuclein oligomers are toxic. Proc Natl Acad Sci U S A 108:4194 4199. doi:10.1073/pnas.1100976108

17. Spillantini MG, Schmidt ML, Lee VM et al (1997) Alpha-synuclein in Lewy bodies. Nature 388:839-840. doi:10.1038/42166

18. Spillantini MG, Crowther RA, Jakes R et al (1998) Synuclein in filamentous inclusions of Lewy bodies from Parkinson's disease and dementia with Lewy bodies. Proc Natl Acad Sci 95:64696473. doi:10.1073/pnas.95.11.6469

19. Galvin JE, Uryu K, Lee VM, Trojanowski JQ (1999) Axon pathology in Parkinson's disease and Lewy body dementia hippocampus contains alpha-, beta-, and gamma-synuclein. Proc Natl Acad Sci U S A 96:13450-13455. doi:10.1073/pnas.96.23.13450

20. Braak H, Ghebremedhin E, Rüb U et al (2004) Stages in the development of Parkinson's disease-related pathology. Cell Tissue Res 318:121-134. doi:10.1007/s00441-004-0956-9

21. Cookson MR (2005) The biochemistry of Parkinson's disease. Annu Rev Biochem 74:29-52. doi:10.1146/annurev. biochem.74.082803.133400

22. Pyszko JA, Strosznajder JB (2014) The key role of sphingosine kinases in the molecular mechanism of neuronal cell survival and death in an experimental model of Parkinson's disease. Folia Neuropathol 3:260-269. doi:10.5114/fn.2014.45567

23. Jesko H, Okada T, Strosznajder RP, Nakamura S (2014) Sphingosine kinases modulate the secretion of amyloid $\beta$ precursor protein from SH-SY5Y neuroblastoma cells: the role of $\alpha$-synuclein. Folia Neuropathol 52:70-78. doi:10.5114/fn.2014.41745

24. Surguchev A, Surguchov A (2015) Effect of alpha-synuclein on membrane permeability and synaptic transmission: a clue to neurodegeneration? J Neurochem 132:619-621. doi:10.1111/jnc.13045
25. Pacheco CR, Morales CN, Ramírez AE et al (2015) Extracellular alpha-synuclein alters synaptic transmission in brain neurons by perforating the neuronal plasma membrane. JNeurochem 132: 731-741. doi:10.1111/jnc. 13060

26. Desplats P, Lee H-J, Bae E-J et al (2009) Inclusion formation and neuronal cell death through neuron-to-neuron transmission of alpha-synuclein. Proc Natl Acad Sci U S A 106:13010-13015. doi:10.1073/pnas.0903691106

27. Luk KC, Song C, O’Brien P et al (2009) Exogenous alpha-synuclein fibrils seed the formation of Lewy body-like intracellular inclusions in cultured cells. Proc Natl Acad Sci U S A 106:2005120056. doi:10.1073/pnas.0908005106

28. Ouzounoglou E, Kalamatianos D, Emmanouilidou E et al (2014) In silico modeling of the effects of alpha-synuclein oligomerization on dopaminergic neuronal homeostasis. BMC Syst Biol 8:54 doi:10.1186/1752-0509-8-54

29. Adamczyk A, Czapski GA, Kaźmierczak A, Strosznajder JB (2009) Effect of N-methyl-Daspartate (NMDA) receptor antagonists on alpha-synuclein-evoked neuronal nitric oxide synthase activation in the rat brain. Pharmacol Rep 61:1078-1085

30. Lee H-J, Bae E-J, Lee S-J (2014) Extracellular $\alpha$-synuclein-a novel and crucial factor in Lewy body diseases. Nat Rev Neurol 10:9298. doi:10.1038/nrneurol.2013.275

31. Lee HJ, Suk JE, Patrick C et al (2010) Direct transfer of alphasynuclein from neuron to astroglia causes inflammatory responses in synucleinopathies. J Biol Chem 285:9262-9272. doi:10.1074 /jbc.M109.081125

32. Emmanouilidou E, Elenis D, Papasilekas T et al (2011) Assessment of a-synuclein secretion in mouse and human brain parenchyma. PLoS One 6:1-9. doi:10.1371/journal.pone.0022225

33. Danzer KM, Haasen D, Karow AR et al (2007) Different species of alpha-synuclein oligomers induce calcium influx and seeding. J Neurosci 27:9220-9232. doi:10.1523/JNEUROSCI.2617-07.2007

34. Danzer KM, Krebs SK, Wolff M et al (2009) Seeding induced by alpha-synuclein oligomers provides evidence for spreading of alpha-synuclein pathology. J Neurochem 111:192-203. doi:10.1111 jj.1471-4159.2009.06324.x

35. Nonaka T, Watanabe ST, Iwatsubo T, Hasegawa M (2010) Seeded aggregation and toxicity of \{alpha\}-synuclein and tau: cellular models of neurodegenerative diseases. J Biol Chem 285:3488534898. doi:10.1074/jbc.M110.148460

36. Hansen C, Angot E, Bergström AL et al (2011) $\alpha$-Synuclein propagates from mouse brain to grafted dopaminergic neurons and seeds aggregation in cultured human cells. J Clin Invest 121:715-725. doi:10.1172/JCI43366

37. Mizugishi K, Yamashita T, Olivera A et al (2005) Essential role for sphingosine kinases in neural and vascular development essential role for sphingosine kinases in neural and vascular development. Mol Cell Biol 25:11113-11121. doi:10.1128/MCB.25.24.11113

38. Cuvillier O, Pirianov G, Kleuser B et al (1996) Suppression of ceramide-mediated programmed cell death by sphingosine-1-phosphate. Nature 381:800-803

39. Kanno T, Nishizaki T, Proia RL et al (2010) Regulation of synaptic strength by sphingosine 1-phosphate in the hippocampus. Neuroscience 171:973-980. doi:10.1016/j. neuroscience.2010.10.021

40. Couttas TA, Kain N, Daniels B et al (2014) Loss of the neuroprotective factor sphingosine 1- phosphate early in Alzheimer's disease pathogenesis. Acta Neuropathol Commun 2:9. doi:10.1186/20515960-2-9

41. Pyszko J, Strosznajder JB (2014) Sphingosine kinase 1 and sphingosine-1-phosphate in oxidative stress evoked by 1-methyl-4phenylpyridinium (MPP+) in human dopaminergic neuronal cells. Mol Neurobiol 50:38-48. doi:10.1007/s12035-013-8622-4

42. Czubowicz K, Cieślik M, Pyszko J et al (2015) Sphingosine-1phosphate and its effect on glucose deprivation/glucose reload 
stress: from gene expression to neuronal survival. Mol Neurobiol 51:1300-1308. doi:10.1007/s12035-014-8807-5

43. Czubowicz K, Strosznajder R (2014) Ceramide in the molecular mechanisms of neuronal cell death. The role of sphingosine-1-phosphate. Mol Neurobiol 1-12. doi: 10.1007/s12035-013-8606-4

44. Ceccom J, Loukh N, Lauwers-Cances V et al (2014) Reduced sphingosine kinase-1 and enhanced sphingosine 1-phosphate lyase expression demonstrate deregulated sphingosine 1-phosphate signaling in Alzheimer's disease. Acta Neuropathol Commun 2:12. doi:10.1186/2051-5960-2-12

45. Sivasubramanian M, Kanagaraj N, Dheen ST, Tay SSW (2015) Sphingosine kinase 2 and sphingosine-1-phosphate promotes mitochondrial function in dopaminergic neurons of mouse model of Parkinson's disease and in MPP+ -treated MN9D cells in vitro. Neurosci 290:636-648. doi:10.1016/j.neuroscience.2015.01.032

46. Kincaid B, Bossy-Wetzel E (2013) Forever young: SIRT3 a shield against mitochondrial meltdown, aging, and neurodegeneration. Front Aging Neurosci. doi:10.3389/fnagi.2013.00048

47. Lavu S, Boss O, Elliott PJ, Lambert PD (2008) Sirtuins-novel therapeutic targets to treat ageassociated diseases. Nat Rev Drug Discov 7:841-853. doi:10.1038/nrd2920-c1

48. Kim HS, Vassilopoulos A, Wang RH et al (2011) SIRT2 maintains genome integrity and suppresses tumorigenesis through regulating APC/C activity. Cancer Cell 20:487-499. doi:10.1016/j. ccr.2011.09.004

49. Zhong L, Mostoslavsky R (2011) Fine tuning our cellular factories: sirtuins in mitochondrial biology. Cell Metab 13:621-626. doi:10.1016/j.cmet.2011.05.004

50. Guo YJ, Dong SY, Cui XX, Feng Y, Liu T, Yin M, Kuo SH, Tan EK et al (2016) Resveratrol alleviates MPTP-induced motor impairments and pathological changes by autophagic degradation of $\alpha$ synuclein via SIRT1-deacetylated LC3. Mol Nutr Food Res 60: 2161-2175. doi:10.1002/mnfr.201600111

51. Ng F, Wijaya L, Tang BL (2015) SIRT1 in the brain-connections with aging-associated disorders and lifespan. Front Cell Neurosci 9: 64. doi:10.3389/fncel.2015.00064

52. Min SW, Cho SH, Zhou Y et al (2010) Acetylation of tau inhibits its degradation and contributes to tauopathy. Neuron 67:953-966. doi:10.1016/j.neuron.2010.08.044

53. Wang XF, Liu DX, Liang Y, Xing LL, Zhao WH, Qin XX, Shang DS, Li B et al (2016) Cystatin C shifts APP processing from amyloid- $\beta$ production towards non-amyloidgenic pathway in brain endothelial cells. PLoS One 11, e0161093. doi:10.1371/journal. pone. 0161093

54. Postina R (2008) A closer look at alpha-secretase. Curr Alzheimer Res 5:179-186

55. Outeiro TF, Kontopoulos E, Altmann SM et al (2007) Sirtuin 2 inhibitors rescue alphasynuclein-mediated toxicity in models of Parkinson's disease. Science 317:516-519. doi:10.1126 /science. 1143780

56. Mendoza-Alvarez H, Alvarez-Gonzalez R (1993) Poly(ADP-ribose) polymerase is a catalytic dimer and the automodification reaction is intermolecular. J Biol Chem 268:22575-22580

57. Houtkooper RH, Cantó C, Wanders RJ, Auwerx J (2010) The secret life of NAD+: an old metabolite controlling new metabolic signaling pathways. Endocr Rev 31:194-223. doi:10.1210/er.2009-0026

58. Strosznajder RP, Czubowicz K, Jesko H, Strosznajder JB (2010) Poly(ADP-ribose) metabolism in brain and its role in ischemia pathology. Mol Neurobiol 41:187-196. doi:10.1007/s12035-0108124-6

59. Pieper AA, Blackshaw S, Clements EE et al (2000) Poly(ADPribosyl)ation basally activated by DNA strand breaks reflects glutamate-nitric oxide neurotransmission. Proc Natl Acad Sci U S A 97:1845-1850. doi:10.1073/pnas.97.4.1845

60. Langelier MF, Riccio AA, Pascal JM (2014) PARP-2 and PARP-3 are selectively activated by 5 ' phosphorylated DNA breaks through an allosteric regulatory mechanism shared with PARP-1. Nucleic Acids Res 42:7762-7775. doi:10.1093/nar/gku474

61. Yu S-W, Andrabi SA, Wang H et al (2006) Apoptosis-inducing factor mediates poly(ADPribose) (PAR) polymer-induced cell death. Proc Natl Acad Sci U S A 103:18314-18319. doi:10.1073 /pnas.0606528103

62. Moroni F (2008) Poly(ADP-ribose)polymerase 1 (PARP-1) and postischemic brain damage. Curr Opin Pharmacol 8:96-103. doi:10.1016/j.coph.2007.10.005

63. Cieślik M, Czapski GA, Strosznajder JB (2015) The molecular mechanism of amyloid $\beta 42$ peptide toxicity: the role of sphingosine kinase-1 and mitochondrial sirtuins. PLoS One 10:1-19. doi:10.1371/journal.pone.0137193

64. Don AS, Martinez-Lamenca C, Webb WR et al (2007) Essential requirement for sphingosine kinase 2 in a sphingolipid apoptosis pathway activated by FTY720 analogues. J Biol Chem 282:1583315842. doi:10.1074/jbc.M609124200

65. Lowry OH, Rosebrough NJ, Farr Al RR (1951) Protein measurement with the Folin phenol reagent. J Biol Chem 193:265-275

66. Iwata A, Miura S, Kanazawa I et al (2001) alpha-Synuclein forms a complex with transcription factor Elk-1. J Neurochem 77:239-252. doi:10.1046/j.1471-4159.2001.00232.x

67. Yan $\mathrm{P}, \mathrm{Hu} \mathrm{X}$, Song $\mathrm{H}$ et al (2006) Matrix metalloproteinase-9 degrades amyloid-beta fibrils in vitro and compact plaques in situ. $\mathrm{J}$ Biol Chem 281:24566-24574. doi:10.1074/jbc.M602440200

68. Backstrom JR, Lim GP, Cullen MJ, Tökés ZA (1996) Matrix metalloproteinase-9 (MMP-9) is synthesized in neurons of the human hippocampus and is capable of degrading the amyloidbeta peptide (1-40). J Neurosci 16:7910-7919

69. Brkic M, Balusu S, Libert C, Vandenbroucke RE (2015) Friends or foes: matrix metalloproteinases and their multifaceted roles in neurodegenerative diseases. Mediators Inflamm. doi:10.1155/2015 1620581

70. Wan W, Cao L, Liu L et al (2015) A $\beta(1-42)$ oligomer-induced leakage in an in vitro bloodbrain barrier model is associated with up-regulation of RAGE and metalloproteinases, and down-regulation of tight junction scaffold proteins. J Neurochem 134:382-393. doi: 10.1111 jnc. 13122

71. Ito S, Kimura K, Haneda $\mathrm{M}$ et al (2007) Induction of matrix metalloproteinases (MMP3, MMP12 and MMP13) expression in the microglia by amyloid-beta stimulation via the PI3K/Akt pathway. Exp Gerontol 42:532-537. doi:10.1016/j.exger.2006.11.012

72. Adamczyk A, Kaźmierczak A (2009) Alpha-synuclein inhibits poly (ADP-ribose) polymerase- 1 (PARP-1) activity via NO-dependent pathway. Folia Neuropathol 1:31-33

73. Van Brocklyn JR, Williams JB (2012) The control of the balance between ceramide and sphingosine-1-phosphate by sphingosine kinase: Oxidative stress and the seesaw of cell survival and death. Comp Biochem Physiol - B Biochem Mol Biol 163:26-36. doi:10.1016/j.cbpb.2012.05.006

74. Gomez-Brouchet A, Pchejetski D, Brizuela L et al (2007) Critical role for sphingosine kinase-1 in regulating survival of neuroblastoma cells exposed to amyloid-beta peptide. Mol Pharmacol 72:341349. doi:10.1124/mol.106.033738

75. Pchejetski D, Kunduzova O, Dayon A et al (2007) Oxidative stressdependent sphingosine kinase-1 inhibition mediates monoamine oxidase A-associated cardiac cell apoptosis. Circ Res 100:41-49. doi:10.1161/01.RES.0000253900.66640.34

76. Orr Gandy KA, Obeid LM (2013) Targeting the sphingosine kinase/sphingosine 1-phosphate pathway in disease: review of sphingosine kinase inhibitors. Biochim Biophys Acta - Mol Cell Biol Lipids 1831:157-166. doi:10.1016/j.bbalip.2012.07.002

77. Martinez TN, Chen X, Bandyopadhyay S et al (2012) Ceramide sphingolipid signaling mediates Tumor Necrosis Factor (TNF)-dependent toxicity via caspase signaling in dopaminergic neurons. Mol Neurodegener 7:45. doi:10.1186/1750-1326-7-45 
78. Sofic E, Denisova N, Youdim K et al (2001) Antioxidant and prooxidant capacity of catecholamines and related compounds. Effects of hydrogen peroxide on glutathione and sphingomyelinase activity in pheochromocytoma PC12 cells: potential relevance to age-related diseases. J Neural Transm 108:541-557. doi:10.1007 /s007020170055

79. Thuy AV, Reimann C-M, Hemdan NY, Gräler MH (2014) Sphingosine 1-phosphate in blood: function, metabolism, and fate. Cell Physiol Biochem 34:158-171. doi:10.1159/000362992

80. Yadav RS, Tiwari NK (2014) Lipid integration in neurodegeneration: an overview of Alzheimer's disease. Mol Neurobiol 1-9. doi: 10.1007/s12035-014-8661-5

81. Thomas B, Mandir AS, West N et al (2011) Resistance to MPTPNeurotoxicity in alphasynuclein knockout mice is complemented by human alpha-synuclein and associated with increased beta-synuclein and Akt activation. PLoS One. doi:10.1371/journal. pone.0016706

82. Kim JY, Jeon BS, Kim HJ, Ahn TB (2013) Nanomolar concentration of alpha-synuclein enhances dopaminergic neuronal survival via Akt pathway. Neural Regen Res 8:3269-3274. doi:10.3969/j. issn.1673-5374.2013.35.001

83. Seo JH, Rah JC, Choi SH et al (2002) Alpha-synuclein regulates neuronal survival via Bcl-2 family expression and PI3/Akt kinase pathway. FASEB J 16:1826-1828. doi:10.1096/fj.02-0041fje

84. Liu H, Sugiura M, Nava VE et al (2000) Molecular cloning and functional characterization of a novel mammalian sphingosine kinase type 2 isoform. J Biol Chem 275:19513-19520. doi:10.1074 /jbc.M002759200

85. Clark J, Clore EL, Zheng K et al (2010) Oral N-Acetyl-cysteine attenuates loss of dopaminergic terminals in $\alpha$-synuclein overexpressing mice. PLoS One. doi:10.1371/journal.pone.0012333

86. Adamczyk A, Strosznajder JB (2006) Alpha-synuclein potentiates $\mathrm{Ca} 2+$ influx through voltage-dependent $\mathrm{Ca} 2+$ channels. Neuroreport 17:1883-1886. doi:10.1097/WNR.0b013 e3280115185
87. Gassowska M, Cieślik M, Wilkaniec A, Strosznajder JB (2014) Sphingosine kinases/sphingosine-1-phosphate and death signalling in APP-transfected cells. Neurochem Res 2:1-8. doi:10.1007 /s11064-014-1240-3

88. Czapski GA, Gassowska M, Wilkaniec A et al (2013) Extracellular alpha-synuclein induces calpain-dependent overactivation of cyclin-dependent kinase 5 in vitro. FEBS Lett 587:3135-3141. doi:10.1016/j.febslet.2013.07.053

89. Tabner BJ, Turnbull S, El-Agnaf O, Allsop D (2001) Production of reactive oxygen species from aggregating proteins implicated in Alzheimer's disease, Parkinson's disease and other neurodegenerative diseases. Curr Top Med Chem 1:507-517. doi:10.2174 $/ 1568026013394822$

90. Turnbull S, Tabner BJ, El-Agnaf OM et al (2001) $\alpha$-synuclein implicated in Parkinson's disease catalyses the formation of hydrogen peroxide in vitro. Free Radic Biol Med 30:1163-1170. doi:10.1016/S0891-5849(01)00513-5

91. Salvador JM, Brown-Clay JD, Fornace AJ (2013) Gadd45 in stress signaling, cell cycle control, and apoptosis. Adv Exp Med Biol 793: 1-19. doi:10.1007/978-1-4614-8289-5-1

92. Watanabe S, Ageta-Ishihara N, Nagatsu S et al (2014) SIRT1 overexpression ameliorates a mouse model of SOD1-linked amyotrophic lateral sclerosis via HSF1/HSP70i chaperone system. Mol Brain 7:62. doi:10.1186/s13041-014-0062-1

93. Bai P, Cantó C, Oudart H et al (2011) PARP-1 inhibition increases mitochondrial metabolism through SIRT1 activation. Cell Metab 13:461-468. doi:10.1016/j.cmet.2011.03.004

94. Bai P, Canto C, Brunyánszki A et al (2011) PARP-2 regulates SIRT1 expression and whole body energy expenditure. Cell Metab 13:450-460. doi:10.1016/j.cmet.2011.03.013

95. Strosznajder JB, Czapski GA, Adamczyk A, Strosznajder RP (2012) Poly(ADP-ribose) polymerase-1 in amyloid beta toxicity and Alzheimer's disease. Mol Neurobiol 46:78-84. doi:10.1007 /s12035-012-8258-9 